\title{
Review \\ Bench-to-bedside review: Sepsis, severe sepsis and septic shock - does the nature of the infecting organism matter?
}

Hongmei Gao, Timothy W Evans and Simon J Finney

Adult Intensive Care Unit, Royal Brompton Hospital, Sydney Street, London SW3 6NP, UK

Corresponding author: Timothy Evans, t.evans@rbht.nhs.uk

Published: 6 May 2008

This article is online at http://ccforum.com/content/12/3/213

(c) 2008 BioMed Central Ltd
Critical Care 2008, 12:213 (doi:10.1186/cc6862)

patients with established sepsis using the best evidence available currently [6].

International guidelines concerning the management of patients with sepsis, septic shock and multiple organ failure make no reference to the nature of the infecting organism. Indeed, most clinical signs of sepsis are nonspecific. In contrast, in vitro data suggest that there are mechanistic differences between bacterial, viral and fungal sepsis, and imply that pathogenetic differences may exist between subclasses such as Gram-negative and Grampositive bacteria. These differences are reflected in different cytokine profiles and mortality rates associated with Gram-positive and Gram-negative sepsis in humans. They also suggest that putative anti-mediator therapies may act differently according to the nature of an infecting organism. Data from some clinical trials conducted in severe sepsis support this hypothesis. It is likely that potential new therapies targeting, for example, Toll-like receptor pathways will require knowledge of the infecting organism. The advent of new technologies that accelerate the identification of infectious agents and their antimicrobial sensitivities may allow better tailored anti-mediator therapies and administration of antibiotics with narrow spectra and known efficacy.

\section{Introduction}

Sepsis and its sequelae, namely severe sepsis, septic shock and multiple organ failure, dominate the case load of noncoronary intensive care units (ICUs). Despite a fall in mortality, deaths attributable to sepsis have risen in developed countries as the incidence increases in an ageing population [1,2]. Moreover, patients who survive suffer considerable morbidity and score poorly in many domains of health-related quality of life assessments $[3,4]$. Hence, sepsis is the focus of many quality improvement initiatives. The US Institute for Healthcare Improvement's '5 million lives' campaign aims to reduce the incidence of nosocomial sepsis [5]. Furthermore, the Surviving Sepsis Campaign (instigated by the European Society of Intensive Care Medicine, International Sepsis Forum and Society of Critical Care Medicine) aims to harmonize the clinical management of
Louis Pasteur was the first to link micro-organisms with human disease when he identified the streptococcal aetiology of puerperal sepsis [7]. It is now known that sepsis also arises after infections with a range of micro-organisms that include viruses, fungi and protozoa. However, neither the Surviving Sepsis Campaign nor the guidelines of the American College of Chest Physicians and Society of Critical Care Medicine [8] make any reference to whether specific infectious agents influence the natural history or therapy of an episode of sepsis. Similarly, standard definitions do not focus on the site of infection. Thus, sepsis is often considered as a single entity, with little or no reference to the causative agent or the anatomical focus of infection. Does this mean that the nature of the organism has no influence?

Clinically, the nature of the organism is critical in that many possess specific virulence factors that have considerable prognostic significance. For example, Panton-Valentine leukocidin secreted by staphylococci contributes to the development of a rapidly progressive haemorrhagic necrotizing pneumonia in immunocompetent patients [9] and a particularly high mortality rate [10]. It is likely that other microbial and host factors influence the effects of Panton-Valentine leukocidin [11,12]. Similarly, other bacterial subgroups secrete toxins such as superantigenic toxic shock syndrome toxin 1, exfoliative toxin, botulinum toxin and tetanus toxin. All are associated with additional mortality above that attributable to bacterial infection per se. However, aside from virulence factors specific to certain organisms, differences are also detectable in association with broader microbial classifications. Most data exist for differences between Grampositive and Gram-negative infections [13].

$I C U=$ intensive care unit; IFN = interferon; IL = interleukin; LPS = lipopolysaccharide; PCR = polymerase chain reaction; TLR = Toll-like receptor; $\mathrm{TNF}=$ tumour necrosis factor. 


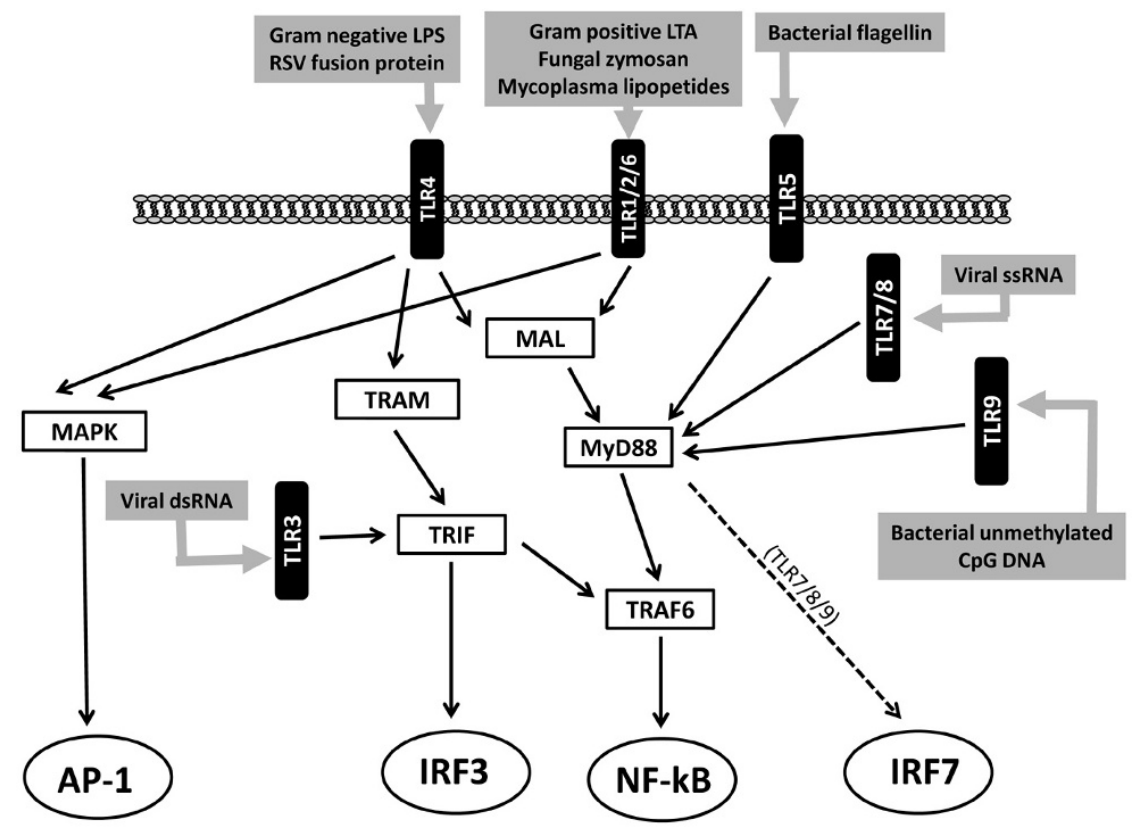

Simplified schematic of intracellular signalling for TLRs. AP, activator protein; CpG DNA, cytosine-guanine dinucleotides; dsRNA, double-stranded ribonucleic acid; IRF, interferon response factor; LPS, lipopolysaccharide; LTA, lipoteichoic acid; MAL, MyD88-adaptor-like; MAPK, mitogen-

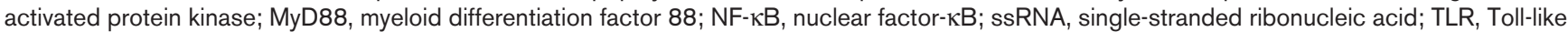
receptor; TRAM, Toll-receptor-associated molecule; TRIF, Toll-receptor-associated activator of interferon.

\section{Differences in the host response}

Infectious pathogens are detected by the innate immune system via Toll-like receptors (TLRs). Ten TLRs have been identified, through which most pathogens can be detected. Recognition does not require previous exposure to a pathogen or an enormous range of genome-encoded receptors, such as is associated with the T-cell receptor. TLRs respond to molecular patterns such as unmethylated $\mathrm{CpG}$ dinucleotides that are common in bacteria but uncommon in the host. Mammalian DNA methyltransferases result in methylation of $70 \%$ to $80 \%$ of CpG cytosines [14]. Similarly, TLR4 and TLR2 recognize lipopolysaccharide (LPS) and lipoteichoic acid, structural molecules that are unique to the cell walls of Gram-negative and Gram-positive bacteria, respectively. Whereas bacterial components signal via a single TLR, it is unlikely that whole bacteria signal so exclusively. Indeed, cell wall extracts from Gram-positive and Gram-negative organisms contain components that can activate both receptors $[15,16]$. This lack of absolute dependence on a single receptor has obvious benefits for the host. However, mice deficient in TLR2 and TLR4 are more prone to infections with staphylococci [17] and Salmonella spp. [18], respectively, which suggests that Gram-positive infection may have a TLR2-dominant signal, whereas Gramnegative infections have a TLR4-dominant signal.

The intracellular signalling cascades of the TLRs are illustrated in Figure 1. These converge through common adaptor molecules onto three transcription factors: nuclear factor- $\kappa \mathrm{B}$, activator protein-1, and interferon response factor-1. All three factors result in the upregulation of genes for proinflammatory cytokines such as tumour necrosis factor (TNF)- $\alpha$, $\mathrm{IL}-1$, and the IFNs. However, this convergence of signalling cascades is not reflected in vitro. Specific ligands for receptors result in different but overlapping responses. For example, TLR4 but not TLR2 agonists prolong neutrophil survival [19]. Additionally, cytokine release differs in human trophoblasts [20] and peripheral blood mononuclear cells [21-23] according to bacterial component. Although whole bacteria may signal via several TLRs, there remains divergence in cytokine responses to whole bacteria in vitro [24]. Heat-killed streptococci induce greater IFN- $\gamma$ but less IL-10 release than heat-killed Escherichia coli in a whole blood model [25]. Other investigators have demonstrated that heatkilled staphylococci induce less IL-6, IL-8, IL-1 $\beta$ and TNF- $\alpha$ from neonatal blood than E. coli [26].

These in vitro observations can be extended to the results of clinical studies. Microarray data from 52 patients suggest that different but overlapping sets of genes are upregulated and these sets include genes that are implicated in the inflammatory response [21]. The patient numbers were too small to exclude host interactions. Nevertheless, it is possible that patterns of gene expression in the host could be exploited therapeutically or as a diagnostic tool. Gram-negative disease has been shown to result in greater plasma levels of TNF- $\alpha$ 
than Gram-positive infection [25,27]. Gram-negative meningococcal septicaemia is associated with greater plasma IL-10 and lower IFN- $\gamma$ than Gram-positive sepsis [25]. Others have identified differences in IL-6, IL-18 and procalcitonin levels [21]. However, such differences in cytokine profiles do not manifest overtly in either physiological or clinical differences. Signs such as fever, hypotension and tachycardia, and widely used biochemical markers (for example, raised C-reactive protein) and leucocytosis are nonspecific. By contrast, there may be differences in mortality afforded by the nature of the infecting organism. These differences have not remained constant over time, because it has been observed that the incidence of Gram-negative sepsis is falling whereas that of Gram-positive sepsis has remained steady [1]. Moreover, univariate analyses have suggested that Gram-positive or staphylococcal infections appear to be associated with greater mortality [28-30]. In another multivariate analysis [30] only pseudomonal infections appeared to carry a sigificantly different (higher) mortality rate.

These findings are important because the aetiology of sepsis has changed over time. In the 1980s the most frequently identified organisms were Gram-negative bacteria, often of gastrointestinal origin. More recently Gram-positive bacteria have accounted for the greatest proportion of hospital admissions with sepsis in which an organism is identified $[1,30]$. It is not clear whether this is a consequence of greater use of prostheses and invasive vascular devices [31] or of increasing prevalence of multiresistant organisms (for example, methicillin-resistant Staphylococcus aureus) [32]. Methicillinresistant $S$. aureus is associated with increased ICU length of stay, postoperative complications, treatment costs and mortality [32]. The incidence of fungal sepsis has also increased. In a study of 49 US hospitals, fungi accounted for $11.7 \%$ of bloodstream infections in ICUs [1,33], with an associated mortality of $45 \%$ [33,34]. There are few data describing the cytokine profiles of severe fungaemia or viraemia relative to that of bacterial sepsis. Finally, in around $40 \%$ of cases no organism is identified as the cause of sepsis [30], possibly because of lack of samples, previous antibiotic therapy, or deficiencies in microbiological techniques. It is not known how the different microbial groups are represented within this important subgroup [35].

In summary, the nature of an infectious pathogen influences the mechanism of the host response. This appears teleologically intuitive, because a common strategy would not allow the host to exclude all viruses, intracellular infections, extracellular infections and microbial structures. The corollary is that the effects of any specific anti-mediator therapies may vary according to the nature of the infection.

\section{Differences in the response to therapeutic intervention}

The nature of the infecting organism is critical, primarily for the selection of appropriate antimicrobial agents. Observa- tional studies have demonstrated that the appropriateness of such therapy has the greatest impact on outcome in sepsis [35].

Patients with Gram-positive or Gram-negative infections have responded differently in some clinical trials targeting mediators of the inflammatory response [36]. Unfortunately, not all have reported efficacy according to the nature of the infecting organism. However, in a randomized, double-blind, placebo-controlled trial of a soluble fusion protein of TNF- $\alpha$ receptor, no adverse events were observed in patients with Gram-negative infection, whereas patients with Gram-positive infection tended to have increased mortality [37]. In contrast, a murine monoclonal antibody directed against human TNF- $\alpha$ tended to reduce mortality in Gram-positive infection, whereas that in Gram-negative infection mortality tended to increase [38]. The platelet-activating factor receptor antagonist BN52021 and the bradykinin antagonist CP-0127 both resulted in reduced mortality in Gram-negative disease, with no effect in patients with Gram-positive infection $[39,40]$. Finally, patients with Gram-positive disease have potentially been harmed in trials of IL-1 receptor antagonists [41] and anti-LPS (HA-1A) [42]. To date, drotrecogin alfa (activated) is the only therapy that has been demonstrated to be efficacious in severe sepsis by a large, randomized, doubleblind, placebo-controlled trial. Drotrecogin alfa appears to be equally effective in patient with the broader classifications of Gram-positive, Gram-negative, or fungal sepsis [43,44]. When examined at the level of individual organisms, the data suggest that some differences in therapeutic response may exist. Indeed, patients with Streptococcus pneumoniae infection may have the greatest reduction in mortality with drotrecogin alfa therapy [44], although this observation was not formally evaluated.

There is considerable interest in the therapeutic opportunities afforded by the discovery of TLRs. Inhibition of signalling pathways may limit an over-exuberant and possibly damaging host inflammatory response. Several therapies targeting the TLR4 pathway are under development. Being directed at TLR4, these therapies may be efficacious only in bacterial Gram-negative sepsis, and their effectiveness will thus be critically dependent on the nature of the infecting organism. For example, TAK-242 is a small molecule antagonist that reduces LPS-induced production of nitric oxide, IL-1 $\beta$, IL-6 and TNF- $\alpha$ by human blood mononuclear cells $[45,46]$. It is selective for TLR4 and not TLR2, TLR3 or TLR9 signalling. In vivo, it improves survival when it is administered to mice even after a normally fatal LPS challenge [47]. TAK-242 is currently undergoing phase III evaluation in a multicentre, randomized, placebo-controlled study of patients treated within 36 hours of the onset of severe sepsis and concomitant respiratory and cardiovascular failure [48]. The primary end-point of the study is 28-day all-cause mortality. An earlier study of TAK-242 [49] was stopped after enrolling 277 patients; data are yet to be reported. Alternatively, E5564, or 
eritoran, is a synthetic lipodisaccharide that antagonizes LPS [50]. In vivo, E5564 blocks the induction of cytokines by LPS and reduces lethality after injection of LPS or bacteria into mice [50]. Moreover, in a double-blind, placebo-controlled study, a single dose of E5564 caused a dose-dependent reduction in temperature, heart rate, clinical symptoms, C-reactive protein, white cell count, TNF- $\alpha$, and IL- 6 after LPS injection [51]. E5564 is being evaluated in a phase III, double blind, placebo-controlled study conducted in patients within 12 hours of onset of severe sepsis [52]. The primary outcome measure is 28-day survival. Finally, two other agents yet to be investigated are CRX-526 (a synthetic lipid A mimetic and thus TLR4 agonist) [53] and soluble decoy TLRs [54-56].

\section{Determination of the infecting organism}

Current standard microbiological techniques identify infecting organisms after culture of a clinical isolate in conditions suitable for replication of the infectious agent. This may be difficult with fastidious organisms or if patients have received antibiotics. Preliminary classification is usually possible within 24 hours, with full species identification and antimicrobial sensitivity data becoming available 48 to 72 hours after blood sampling. The slowness of the investigation usually mandates the use of 'best guess', and often broad spectrum, antibiotics while awaiting results.

Several techniques are being developed that accelerate the identification of infecting organisms. Many detect nucleotide sequences specific to pathogens in blood after standard culture. Techniques include fluorescent in situ hybridization and PCR assays [57]. The wide range of possible pathogens requires the use of many PCR conditions; this can be circumvented by using custom printed DNA microarrays. Typically, these detect panels of 20 to 40 gene sequences to discern the most common isolates [58]. Furthermore, sequences that correlate with antimicrobial resistance can be detected to guide appropriate therapy. It is theoretically possible to undertake PCR-based amplification of sufficient magnitude to detect low copy numbers of DNA sequences, thereby eliminating the requirement for an initial period of standard culture. The utility of these techniques is limited currently by difficulties in differentiating contaminants and nonliving or degraded bacteria from clinically relevant isolates. Finally, infrared vibrational spectroscopy allows the identification of bacterial specific proteins in whole blood [59]. This emerging technique does not require amplification or extraction of the proteins.

No system has been evaluated extensively in clinical practice, but they offer considerable potential advantages. First, they may facilitate the use of antibiotics with narrower spectra but known efficacy against a particular organism; this may minimize the development of multidrug resistant bacteria and infections such as Clostridium difficile diarrhoea. Second, they promote better understanding of the heterogeneity of infection in sepsis. Finally, they may allow the use of some of the specific antimediator therapies that are being investigated.

\section{This article is part of a review series on Infection, edited by Steven Opal.}

Other articles in the series can be found online at http://ccforum.com/articles/ theme-series.asp?series=CC_Infection

\section{Conclusion}

The nature of an infecting organism is critically important. Clinically, specific virulence factors such as exotoxins influence the manifestations, morbidity and mortality of sepsis. Furthermore, the nature of the pathogens influences the mechanism of the host response and therefore the response to any therapy. From the perspective of the physician, early identification of an infectious agent will allow confirmation that infection underlies an inflammatory process, allow the use of efficacious and narrow spectrum antibiotics, and may open the door to new therapies targeted at pathogen-specific inflammatory pathways.

\section{Competing interests}

The authors declare that they have no competing interests.

\section{Authors' contributions}

HG, TE, and SF planned, drafted, read, and approved the final manuscript.

\section{References}

1. Martin GS, Mannino DM, Eaton S, Moss M: The epidemiology of sepsis in the United States from 1979 through 2000. N Engl J Med 2003, 348:1546-1554.

2. Angus DC, Linde-Zwirble WT, Lidicker J, Clermont G, Carcillo J, Pinsky MR: Epidemiology of severe sepsis in the United States: analysis of incidence, outcome, and associated costs of care. Crit Care Med 2001, 29:1303-1310.

3. Kaarlola A, Pettila V, Kekki P: Quality of life six years after intensive care. Intensive Care Med 2003, 29:1294-1299.

4. Perl TM, Dvorak L, Hwang T, Wenzel RP: Long-term survival and function after suspected gram-negative sepsis. JAMA 1995, 274:338-345.

5. Protecting 5 million lives from harm [http://www.ihi.org/lHI/ Programs/Campaign/Campaign.htm]

6. Dellinger RP, Carlet JM, Masur H, Gerlach H, Calandra T, Cohen J, Gea-Banacloche J, Keh D, Marshall JC, Parker MM, Ramsay G, Zimmerman JL, Vincent JL, Levy MM; Surviving Sepsis Campaign Management Guidelines Committee: Surviving Sepsis Campaign guidelines for management of severe sepsis and septic shock. Crit Care Med 2004, 32:858-873.

7. Pasteur L: Septicemie puerperale. Bulletin de l'Academie de Medecine 1879, 8:271-274.

8. Anonymous: American College of Chest Physicians/Society of Critical Care Medicine Consensus Conference: definitions for sepsis and organ failure and guidelines for the use of innovative therapies in sepsis. Crit Care Med 1992, 20:864-874.

9. Labandeira-Rey M, Couzon F, Boisset S, Brown EL, Bes M, Benito Y, Barbu EM, Vazquez V, Höök M, Etienne J, Vandenesch F, Bowden MG: Staphylococcus aureus Panton-Valentine leukocidin causes necrotizing pneumonia. Science 2007, 315: 1130-1133.

10. Gillet $Y$, Issartel B, Vanhems P, Fournet JC, Lina G, Bes M, Vandenesch F, Piémont $Y$, Brousse N, Floret D, Etienne J: Association between Staphylococcus aureus strains carrying gene for Panton-Valentine leukocidin and highly lethal necrotising 
pneumonia in young immunocompetent patients. Lancet 2002, 359:753-759.

11. Hamilton SM, Bryant AE, Carroll KC, Lockary V, Ma Y, Mclndoo E, Miller LG, Perdreau-Remington F, Pullman J, Risi GF, Salmi DB, Stevens DL: In vitro production of panton-valentine leukocidin among strains of methicillin-resistant Staphylococcus aureus causing diverse infections. Clin Infect Dis 2007, 45:1550-1558.

12. Ellington MJ, Hope R, Ganner M, Ganner M, East C, Brick G, Kearns AM: Is Panton-Valentine leucocidin associated with the pathogenesis of Staphylococcus aureus bacteraemia in the UK? J Antimicrob Chem 2007, 60:402-405.

13. Opal SM, Cohen J: Clinical gram-positive sepsis: does it fundamentally differ from gram-negative bacterial sepsis? Crit Care Med 1999, 27:1608-1616.

14. Jabbari K, Bernardi G: Cytosine methylation and CpG, TpG (CpA) and TpA frequencies. Gene 2004, 333:143-149.

15. Hirschfeld M, Ma Y, Weis JH, Vogel SN, Weis JJ: Cutting edge: repurification of lipopolysaccharide eliminates signaling through both human and murine toll-like receptor 2. J Immunol 2000, 165:618-622

16. Hashimoto M, Imamura Y, Yasuoka J, Kotani S, Kusumoto S, Suda $Y$ : A novel cytokine-inducing glycolipid isolated from the lipoteichoic acid fraction of Enterococcus hirae ATCC 9790: a fundamental structure of the hydrophilic part. Glycoconj $J$ 1999, 16:213-221.

17. Takeuchi O, Hoshino K, Akira S: Cutting edge: TLR2-deficient and MyD88-deficient mice are highly susceptible to Staphylococcus aureus infection. J Immunol 2000, 165:5392-5396.

18. Bernheiden M, Heinrich JM, Minigo G, Schutt C, Stelter F, Freeman M, Golenbock D, Jack RS: LBP, CD14, TLR4 and the murine innate immune response to a peritoneal Salmonella infection. J Endotoxin Res 2001, 7:447-450.

19. Sabroe I, Prince LR, Jones EC, Horsburgh MJ, Foster SJ, Vogel SN, Dower SK, Whyte MK: Selective roles for Toll-like receptor (TLR)2 and TLR4 in the regulation of neutrophil activation and life span. J Immuno/ 2003, 170:5268-5275.

20. Abrahams VM, Bole-Aldo P, Kim YM, Straszewski-Chavez SL, Chaiworapongsa T, Romero R, Mor G: Divergent trophoblast responses to bacterial products mediated by TLRs. J Immunol 2004, 173:4286-4296.

21. Feezor RJ, Oberholzer C, Baker HV, Novick D, Rubinstein M, Moldawer LL, Pribble J, Souza S, Dinarello CA, Ertel W, Oberholzer A: Molecular characterization of the acute inflammatory response to infections with Gram-negative versus Gram-positive bacteria. Infect Immun 2003, 71:5803-5813.

22. Ghosh TK, Mickelson DJ, Fink J, Solberg JC, Inglefield JR, Hook D, Gupta SK, Gibson S, Alkan SS: Toll-like receptor (TLR) 2-9 agonists-induced cytokines and chemokines: I. Comparison with T cell receptor-induced responses. Cell Immunol 2006, 243:48-57

23. Iwadou H, Morimoto $Y$, Iwagaki H, Sinoura S, Chouda $Y$, Kodama M, Yoshioka T, Saito S, Yagi T, Tanaka N: Differential cytokine response in host repsonse in host defence mechanisms triggered by Gram-negative and Gram-positive bacteria, and the roles of gabexate mesilate, a synthetic protease inhibitor. J Intern Med Res 2002, 30:99-108.

24. Paul-Clark MJ, McMaster SK, Belcher E, Sorrentino R, Anandarajah J, Fleet M, Sriskandan S, Mitchell JA: Differential effects of Gram-positive versus Gram-negative bacteria on NOSII and TNFalpha in macrophages: role of TLRs in synergy between the two. Br J Pharmaco/ 2006, 148:1067-1075.

25. Bjerre A, Brusletto B, Hoiby EA, Kierulf $P$, Brandtzaeg P: Plasma interferon-gamma and interleukin-10 concentrations in systemic meningococcal disease compared with severe systemic Gram-positive septic shock. Crit Care Med 2004, 32:433-438.

26. Mohamed MA, Cunningham-Rundles S, Dean CR, Hammad TA, Nesin M: Levels of pro-inflammatory cytokines produced from cord blood in-vitro are pathogen dependent and increased in comparison to adult controls. Cytokine 2007, 39:171-177.

27. Fisher CJ Jr, Opal SM, Dhainaut JF, Stephens S, Zimmerman JL, Nightingale P, Harris SJ, Schein RM, Panacek EA, Vincent JL, Foulke GE, Warren EL, Garrard C, Park G, Bodmer MW, Cohen J, Vanderlinden C, Cross AS, Sadoff JC, Fisher CJ, Panacek EA, Warren EL, Gorecki J, Opal SM, Dubin HG, Garner C, Kaye W, Dhainaut JF, Lanore JJ, Mira JP Stephens S, Harris SJ, Bodmer MW, Zimmerman J, Dellinger RP, Taylor RW, Dahl S, Nightingale P, Shelly M, Mortimer A, Edwards JD, Schein RMH, Kett DH,
Quartin A, Pena MA, Vincent JL, Bakker J, Foulke GE, Alberson TE, Walby W, Radcliffe J, Garrard C, Young D, Mcquillam P, Park G, Cohen J, Bellingham G, Vanderlinden C, Burman W, Cross AS, Sadoff JS, Young L: Influence of an anti-tumor necrosis factor monoclonal antibody on cytokine levels in patients with sepsis. The CB0006 Sepsis Syndrome Study Group. Crit Care Med 1993, 21:318-327.

28. Leibovici L, Samra Z, Konigsberger H, Drucker M, Ashkenazi S, Pitlik SD: Long-term survival following bacteremia or fungemia. Jama 1995, 274:807-812.

29. Brun-Buisson C, Doyon F, Carlet J: Bacteremia and severe sepsis in adults: a multicenter prospective survey in ICUs and wards of $\mathbf{2 4}$ hospitals. French Bacteremia-Sepsis Study Group. Am J Respir Crit Care Med 1996, 154:617-624.

30. Vincent JL, Sakr Y, Sprung CL, Ranieri VM, Reinhart K, Gerlach H, Moreno R, Carlet J, Le Gall JR, Payen D: Sepsis in European intensive care units: results of the SOAP study. Crit Care Med 2006, 34:344-353.

31. Friedman G, Silva E, Vincent JL: Has the mortality of septic shock changed with time. Crit Care Med 1998, 26:2078-2086.

32. Wang JE, Dahle MK, McDonald M, Foster SJ, Aasen AO, Thiemermann C: Peptidoglycan and lipoteichoic acid in gram-positive bacterial sepsis: receptors, signal transduction, biological effects, and synergism. Shock 2003, 20:402-414.

33. Wisplinghoff $H$, Bischoff T, Tallent SM, Seifert H, Wenzel RP Edmond MB: Nosocomial bloodstream infections in US hospitals: analysis of 24,179 cases from a prospective nationwide surveillance study. Clin Infect Dis 2004, 39:309-317.

34. Gudlaugsson O, Gillespie S, Lee K, Vande Berg J, Hu J, Messer S, Herwaldt L, Pfaller M, Diekema D: Attributable mortality of nosocomial candidemia, revisited. Clin Infect Dis 2003, 37: 1172-1177.

35. Llewelyn MJ, Cohen J: Tracking the microbes in sepsis: advancements in treatment bring challenges for microbial epidemiology. Clin Infect Dis 2007, 44:1343-1348.

36. Sriskandan S, Cohen J: Gram-positive sepsis. Mechanisms and differences from gram-negative sepsis. Infect Dis Clin North Am 1999, 13:397-412.

37. Fisher CJ Jr, Agosti JM, Opal SM, Lowry SF, Balk RA, Sadoff JC Abraham E, Schein RM, Benjamin E: Treatment of septic shock with the tumor necrosis factor receptor:Fc fusion protein. The Soluble TNF Receptor Sepsis Study Group. N Engl J Med 1996, 334:1697-1702.

38. Cohen J, Carlet J: INTERSEPT: an international, multicenter, placebo-controlled trial of monoclonal antibody to human tumor necrosis factor-alpha in patients with sepsis. International Sepsis Trial Study Group. Crit Care Med 1996, 24:14311440.

39. Dhainaut JF, Tenaillon A, Le Tulzo Y, Schlemmer B, Solet JP, Wolff M, Holzapfel L, Zeni F, Dreyfuss D, Mira JP, Devathaire F, Guinot P. Platelet-activating factor receptor antagonist BN 52021 in the treatment of severe sepsis: a randomized, double-blind, placebo-controlled, multicenter clinical trial. BN 52021 Sepsis Study Group. Crit Care Med 1994, 22:1720-1728.

40. Fein AM, Bernard GR, Criner GJ, Fletcher EC, Good JT Jr, Knaus WA, Levy H, Matuschak GM, Shanies HM, Taylor RW, Rodell TC: Treatment of severe systemic inflammatory response syndrome and sepsis with a novel bradykinin antagonist, deltibant (CP-0127). Results of a randomized, double-blind, placebo-controlled trial. CP-0127 SIRS and Sepsis Study Group. Jama 1997, 277:482-487.

41. Fisher CJ Jr, Dhainaut JF, Opal SM, Pribble JP, Balk RA, Slotman GJ, Iberti TJ, Rackow EC, Shapiro MJ, Greenman RL, et al.: Recombinant human interleukin 1 receptor antagonist in the treatment of patients with sepsis syndrome. Results from a randomized, double-blind, placebo-controlled trial. Phase III rhlL-1ra Sepsis Syndrome Study Group. Jama 1994, 271: 1836-1843.

42. Anonymous: The French National Registry of HA-1A (Centoxin) in septic shock. A cohort study of 600 patients. The National Committee for the Evaluation of Centoxin. Arch Intern Med 1994, 154:2484-2491.

43. Bernard GR, Vincent JL, Laterre PF, LaRosa SP, Dhainaut JF, Lopez-Rodriguez A, Steingrub JS, Garber GE, Helterbrand JD, Ely EW, Fisher CJ Jr; Recombinant human protein C Worldwide Evaluation in Severe Sepsis (PROWESS) study group: Efficacy and safety of recombinant human activated protein $\mathrm{C}$ for severe 
sepsis. N Engl J Med 2001, 344:699-709.

44. Opal SM, Garber GE, LaRosa SP, Maki DG, Freebairn RC, Kinasewitz GT, Dhainaut JF, Yan SB, Williams MD, Graham DE, Nelson DR, Levy H, Bernard GR: Systemic host responses in severe sepsis analyzed by causative microorganism and treatment effects of drotrecogin alfa (activated). Clin Infect Dis 2003, 37:50-58.

45. li M, Matsunaga N, Hazeki K, Nakamura K, Takashima K, Seya T, Hazeki O, Kitazaki T, lizawa Y: A novel cyclohexene derivative, ethyl (6R)-6-[N-(2-Chloro-4-fluorophenyl)sulfamoyl]cyclohex1-ene-1-carboxylate (TAK-242), selectively inhibits toll-like receptor 4-mediated cytokine production through suppression of intracellular signaling. Mol Pharmacol 2006, 69:12881295.

46. Yamada $M$, Ichikawa $T$, li $M$, Sunamoto $M$, Itoh $K$, Tamura $N$, Kitazaki T: Discovery of novel and potent small-molecule inhibitors of $\mathrm{NO}$ and cytokine production as antisepsis agents: synthesis and biological activity of alkyl 6-(N-substituted sulfamoyl)cyclohex-1-ene-1-carboxylate. J Med Chem 2005, 48:7457-7467.

47. Sha T, Sunamoto M, Kitazaki T, Sato J, li M, lizawa Y: Therapeutic effects of TAK-242, a novel selective Toll-like receptor 4 signal transduction inhibitor, in mouse endotoxin shock model. Eur J Pharmacol 2007, 571:231-239.

48. A Study of the Safety and Efficacy of TAK-242 in Subjects With Sepsis-Induced Cardiovascular and Respiratory Failure [http://www.clinicaltrials.gov/ct2/show/NCT00633477?term= NCT00633477\&rank=1]

49. A Study To Evaluate Efficacy \& Safety Of TAK-242 In Adults With Severe Sepsis [http://www.clinicaltrials.gov/ct2/show/ NCT00143611 ?term=NCT00143611\&rank=1]

50. Mullarkey M, Rose JR, Bristol J, Kawata T, Kimura A, Kobayashi S, Przetak M, Chow J, Gusovsky F, Christ WJ, Rossignol DP: Inhibition of endotoxin response by e5564, a novel Toll-like receptor 4-directed endotoxin antagonist. J Pharmacol Exp Ther 2003, 304:1093-1102.

51. Lynn M, Rossignol DP, Wheeler JL, Kao RJ, Perdomo CA, Noveck R, Vargas R, D'Angelo T, Gotzkowsky S, McMahon FG: Blocking of responses to endotoxin by E5564 in healthy volunteers with experimental endotoxemia. J Infect Dis 2003, 187:631639.

52. ACCESS: A Controlled Comparison of Eritoran Tetrasodium and Placebo in Patients With Severe Sepsis [http://www. clinicaltrials.gov/ct2/results?term $=$ NCT00334828]

53. Fort MM, Mozaffarian A, Stöver AG, Correia Jda S, Johnson DA, Crane RT, Ulevitch RJ, Persing DH, Bielefeldt-Ohmann H, Probst P, Jeffery E, Fling SP, Hershberg RM: A synthetic TLR4 antagonist has anti-inflammatory effects in two murine models of inflammatory bowel disease. J Immunol 2005, 174:6416-6423.

54. Kuroishi T, Tanaka Y, Sakai A, Sugawara Y, Komine K, Sugawara $\mathrm{S}$ : Human parotid saliva contains soluble toll-like receptor (TLR) 2 and modulates TLR2-mediated interleukin-8 production by monocytic cells. Mol Immuno/ 2007, 44:1969-1976.

55. LeBouder E, Rey-Nores JE, Rushmere NK, Grigorov M, Lawn SD, Affolter M, Griffin GE, Ferrara P, Schiffrin EJ, Morgan BP, Labéta MO: Soluble forms of Toll-like receptor (TLR)2 capable of modulating TLR2 signaling are present in human plasma and breast milk. J Immunol 2003, 171:6680-6689.

56. Iwami KI, Matsuguchi T, Masuda A, Kikuchi T, Musikacharoen T, Yoshikai Y: Cutting edge: naturally occurring soluble form of mouse Toll-like receptor 4 inhibits lipopolysaccharide signaling. J Immunol 2000, 165:6682-6686.

57. Peters RP, van Agtmael MA, Danner SA, Savelkoul PH, Vandenbroucke-Grauls CM: New developments in the diagnosis of bloodstream infections. Lancet Infect Dis 2004, 4:751-760.

58. Cleven BE, Palka-Santini M, Gielen J, Meembor S, Kronke M, Krut $\mathrm{O}$ : Identification and characterization of bacterial pathogens causing bloodstream infections by DNA microarray. J Clin Microbiol 2006, 44:2389-2397.

59. Maquelin K, Kirschner C, Choo-Smith LP, Ngo-Thi NA, van Vreeswijk T, Stammler M, Endtz HP, Bruining HA, Naumann D, Puppels GJ: Prospective study of the performance of vibrational spectroscopies for rapid identification of bacterial and fungal pathogens recovered from blood cultures. $J$ Clin Microbiol 2003, 41:324-329. 